\begin{tabular}{|l|c|c|c|r|}
\hline $\begin{array}{l}\text { Cuadernos de Investigación Geográfica } \\
\text { Geographical Research Letters }\end{array}$ & 2017 & N $^{\circ} 43(2)$ & pp. 629-648 & $\begin{array}{r}\text { ISSN 0211-6820 } \\
\text { eISSN 1697-9540 }\end{array}$ \\
\hline
\end{tabular}

DOI: http://doi.org/10.18172/cig.3201

(C) Universidad de La Rioja

\title{
REVISITING THE ANDEAN TROPICAL GLACIER BEHAVIOR DURING THE ANTARCTIC COLD REVERSAL
}

\author{
V. JOMELLI ${ }^{*}$, L. MARTIN ${ }^{2,3}$, P.H. BLARD ${ }^{2}$, \\ V. FAVIER ${ }^{4,5}$, M. VUILLÉ 6 , J.L. CEBALLOS ${ }^{7}$ \\ ${ }^{1}$ Université Paris 1 Pantheon-Sorbonne, CNRS Laboratoire \\ de Géographie Physique, 92195 Meudon, France. \\ ${ }^{2}$ Centre de Recherches Pétrographiques et Géochimiques, CRPG, UMR 7358, \\ CNRS, Université de Lorraine, Vandoeuvre-lès-Nancy, France. \\ ${ }^{3}$ Department of Geosciences, University of Oslo, \\ P.O. Box 1047, Blindern, 0316 Oslo, Norway. \\ ${ }^{4}$ Univ. Grenoble Alpes, LGGE, F-38041 Grenoble, CNRS, France. \\ ${ }^{5}$ IGE, F-38041 Grenoble, France. \\ ${ }^{6}$ Department of Atmospheric and Environmental Sciences, \\ University at Albany, Albany, New York 12222, USA. \\ ${ }^{7}$ Institute for Hydrology, Meteorology and Environmental \\ Studies (IDEAM), Bogota, 07603, Colombia.
}

\begin{abstract}
The sensitivity of tropical glaciers to paleoclimatic conditions that prevailed during the Antarctic cold reversal (ACR, ca. 14.5-12.9 ka) has been the subject of a wide debate. In 2014 a paper suggested that tropical glaciers responded very sensitively to the changing climate during the ACR (Jomelli et al., 2014). In this study, we reexamine the conclusions from this study by recalculating previous chronologies based on $226{ }^{10} \mathrm{Be}$ and $14{ }^{3} \mathrm{He}$ ages respectively, and using the most up-to date production rates for these cosmogenic nuclides in the Tropical Andes. 53 moraines from 25 glaciers were selected from the previous analysis provided by Jomelli et al. (2014) located in Colombia, Peru and Bolivia. We then focused on two distinct calculations. First we considered the oldest moraine and its uncertainty for every glacier representing the preserved evidence of the maximum glacier extents during the last deglaciation period, and binned the results into 5 distinct periods encompassing the Antarctic cold reversal and Younger Dryas (YD) chronozones: pre-ACR, ACR, ACR-YD, YD and post$Y D$ respectively. Results revealed a predominance of pre-ACR and ACR ages, accounting for $60 \%$ of the glaciers. Second we counted the number of moraines per glacier according to the different groups. 21 moraines (40\%) of the selected glaciers belong to the pre-ACR-ACR chronozones while 3 moraines only (5\%) were dated to the YD and YD-Holocene groups. The rest was assigned mostly to the Holocene. These results suggest that moraine records are a very good proxy to document the ACR signal in the Tropical Andes.
\end{abstract}




\section{Revisando el comportamiento de los glaciares tropicales andinos durante la inversión fría Antártica}

RESUMEN. La sensibilidad de los glaciares tropicales a las condiciones de temperatura fría durante la Inversión Fría Antártica (ACR, por sus siglas en inglés, 14.5-12.9 miles de años AP aprox.) ha sido ampliamente discutida. En 2014, un artículo científico revelaba una respuesta de los glaciares tropicales a la tendencia climática de la ARC (Jomelli et al., 2014); sin embargo, en 2015 nuevas producciones científicas cuestionaron la relevancia de tal conclusión. A partir de las nuevas producciónes se procedió a re-examinar las conclusiones previas, recalculando los resultados basados en cronologías $226{ }^{10} \mathrm{Be}$ y $14{ }^{3} \mathrm{He}$. Para esta revisión, se seleccionaron 53 morrenas de 25 glaciares localizados en Colombia, Perú y Bolivia, entre los analizados por Jomelli et al. (2014) y se procedió a realizar dos cálculos diferentes. En primer lugar, se tuvo en cuenta la morrena más antigua y su incertidumbre para cada glaciar, de acuerdo con cinco períodos distintos abarcando ACR y Younger Dryas (YD): pre-ACR, $A C R, A C R-Y D, Y D$ y post-YD respectivamente. Los resultados revelaron el predominio de señales pre-ACR, ACR en el $60 \%$ de los casos. Posteriormente, se contaron el número de morrenas por glaciar, teniendo en cuenta los diferentes grupos. 21 morrenas (40\%) de los glaciares seleccionados corresponden con las cronozonas pre-ACR y ACR mientras que solo tres morrenas (5\%) fueron datadas en los grupos YD y YD-Holoceno. El resto fue asignado principalmente al Holoceno. Estos resultados sugieren que las morrenas son un proxy muy bueno para analizar la señal de ACR en los Andes Tropicales.

Key words: Tropical glaciers, ACR, Younger Dryas, Cosmogenic nuclides.

Palabras clave: Glaciares tropicales, ACR, Younger Dryas, nucleidos cosmogénicos.

Received: 14 December 2016 Accepted: 9 February 2017

* Corresponding author: Vincent Jomelli. Université Paris 1 Pantheon-Sorbonne, CNRS Laboratoire de Géographie Physique, 92195 Meudon, France. E-mail address: vincent. jomelli@lgp.cnrs.fr

\section{Introduction}

Climatic-induced glacier fluctuations during the last deglaciation (18.0-11.5 ka) have been recognized at several localities in the southern hemisphere (Thompson et al., 2000; 2006; Rodbell et al., 2009). One prominent event, the Antarctic cold reversal (ACR, ca. 14.5-12.9 ka) identified as a cold period in the southern polar latitudes, was contemporaneous with the Bølling-Allerød warm period in the northern hemisphere and ended at the onset of the Younger Dryas stadial (YD, ca. 12.8-11.6 ka). This ACR cold event provoked glacier advances in different regions of the southern mid latitudes. In New Zealand, for instance Putnam et al. (2010) documented an advance of the Pukiki 
glacier during this cold event. ACR glacier advances were also identified in Patagonia. Glaciers of the Lago Argentino basin, Southern Patagonian Icefield experienced a major glacial stillstand or re-advance at ca. $13 \mathrm{ka}$ (Strelin et al., 2014). After the ACR period the large ice lobes that filled the eastern reaches of Lago Argentino retreated and separated into individual outlet glaciers. Interestingly, this recession was interrupted only by a stillstand or minor re-advance during the YD at $12.2 \mathrm{ka}$. However the impacts of the ACR cooling event on glaciers located at lower latitudes of the southern hemisphere remained unclear in particular in the tropics. Recently Jomelli et al. (2014) established the chronology of Ritacuba Negro glacier located in the northern tropics of Colombia. The data revealed that the ACR extent of the glacier was larger than during the YD. The analysis was complemented by a synthesis of different published moraine chronologies from the Tropical Andes for the last $15 \mathrm{ka}$. On the basis of a homogenized chronology of all ${ }^{10} \mathrm{Be}$ and ${ }^{3} \mathrm{He}$ moraine ages across the southern Tropical Andes, the authors showed that thier behavior of ACR glacier extents exceeding those of the YD was common to the northern and southern Tropical Andes. Since this publication new ${ }^{10} \mathrm{Be}$ and ${ }^{3} \mathrm{He}$ production rates have been published for the tropical Andes (Martin et al., 2015; Delunel et al., 2016). This could induce possible shifts in the chronologies which may question the accuracy of the conclusions published by Jomelli et al. (2014). Within the scope of this study, we evaluate the impact of these updated production rates on the conclusions of Jomelli et al. (2014).

Thus the main goal of this paper is to revisit the behavior of tropical Andean glaciers during the ACR and YD events. In other words, we investigate if tropical glaciers experienced an advance during the ACR and/or during YD periods and determine when the maximum glacial extent occurred between 14.5 and $11.6 \mathrm{ka}$ ago, and whether it was synchronous between the northern and southern tropical Andes.

To achieve this goal our approach consisted in recalculating the homogenized chronologies in the tropical Andes published by Jomelli et al. (2014) that cover the last 15,000 years using the new regional ${ }^{10} \mathrm{Be}$ and ${ }^{3} \mathrm{He}$ production rates of Martin et al. (2015) and Delunel et al. (2016).

\section{Data}

In this study we used the same database as the one compiled by Jomelli et al. (2014), i.e. late glacial cosmogenic ${ }^{10} \mathrm{Be}$ and ${ }^{3} \mathrm{He}$ moraine chronologies from the Tropical Andes, including data from Venezuela, Colombia, Peru, Bolivia and northern Argentina, but we restrict our dataset to the ages younger than $15 \mathrm{ka}$ (Smith et al., 2005; Farber et al., 2005; Zech et al., 2007, 2009; Glasser et al., 2009; Hall et al., 2009; Licciardi et al., 2009; Rodbell et al., 2009; Smith and Rodbell, 2010; Smith et al., 2011; Jomelli et al., 2011; Bromley et al., 2009, 2011; Blard et al., 2013; Carcaillet et al., 2013) (Table 1 and Fig. 1). The selected glaciers are located in the northern and southern tropics (Kaser, 2001). In the northern tropic, we recalculated the moraine chronologies of two glaciers, Mucubaji located in Venezuela and Ritacuba Negro glacier located in the Sierra Nevada El Cocuy, Cordillera Oriental, Colombia. The Sierra Nevada has twenty summits reaching a maximum elevation of $5300 \mathrm{~m}$ above sea level (a.s.1.) covered by glaciers. 
Table 1. Description of the selected glaciers.

\begin{tabular}{|c|c|c|c|c|c|}
\hline Name glacier & Latitude & $\begin{array}{l}\text { Longitude } \\
\text { (W) }\end{array}$ & $\begin{array}{l}\text { Reference } \\
\text { Altitude } \\
\text { (m a.s.l.) }\end{array}$ & $\begin{array}{l}\text { Cosmogenic } \\
\text { nuclide }\end{array}$ & Reference \\
\hline Mucubaji & N 8.77 & 70.81 & 3804 & $10 \mathrm{Be}$ & Carcaillet et al., 2014 \\
\hline Ritacuba & N 6.50 & 72.33 & 4209 & $10 \mathrm{Be}$ & Jomelli et al., 2014 \\
\hline Laguna Bara & S 9.65 & 77.36 & 4045 & $10 \mathrm{Be}$ & Farber et al., 2005 \\
\hline Quenua Ragra & S 10.01 & 77.25 & 4330 & $10 \mathrm{Be}$ & Smith and Rodbell, 2010 \\
\hline Jeullesh & S 10.01 & 77.27 & 4290 & $10 \mathrm{Be}$ & $\begin{array}{l}\text { Glasser } \text { et al., 2009; } \\
\text { Smith and Rodbell, } 2010\end{array}$ \\
\hline Tuco & S 10.05 & 77.21 & 4310 & $10 \mathrm{Be}$ & $\begin{array}{l}\text { Glasser } \text { et al., 2009; } \\
\text { Smith and Rodbell, } 2010\end{array}$ \\
\hline Mitococha East & S 10.17 & 76.8 & 3829 & $10 \mathrm{Be}$ & Hall et al., 2009 \\
\hline Mitococha & S 10.21 & 76.9 & 4384 & $10 \mathrm{Be}$ & Hall et al., 2009 \\
\hline Jahuacocha & S 10.24 & 76.97 & 4095 & $10 \mathrm{Be}$ & Hall et al., 2009 \\
\hline Carhuacocha & S 10.24 & 76.86 & 4189 & $10 \mathrm{Be}$ & Hall et al., 2009 \\
\hline Gashapampa & S 10.27 & 77.00 & 4569 & $10 \mathrm{Be}$ & Hall et al., 2009 \\
\hline Huanacpatay & S 10.38 & 76.9 & 4541 & $10 \mathrm{Be}$ & Hall et al., 2009 \\
\hline Tucarhuay & S 13.38 & 72.58 & 4307 & $10 \mathrm{Be}$ & Licciardi et al., 2009 \\
\hline Rio Blanco & S 13.38 & 72.56 & 4047 & $10 \mathrm{Be}$ & Licciardi et al., 2009 \\
\hline Sisaypampa & S 13.34 & 72.51 & 4506 & $10 \mathrm{Be}$ & Licciardi et al., 2009 \\
\hline San Franc & S 15.97 & 68.53 & 4752 & $10 \mathrm{Be}$ & Zech et al., 2007 \\
\hline Zongo & S 16.13 & 68.17 & 3489 & $10 \mathrm{Be}$ & Smith et al., 2005 \\
\hline Telata & S 16.26 & 68.11 & 4529 & $10 \mathrm{Be}$ & Jomelli et al., 2011 \\
\hline Illimani & S 16.57 & 67.79 & 4052 & $10 \mathrm{Be}$ & Smith et al., 2011 \\
\hline Huara Loma & S 17.21 & 66.26 & 4213 & $10 \mathrm{Be}$ & Zech et al., 2007 \\
\hline Riosutiru & S 17.23 & 66.44 & 3930 & $10 \mathrm{Be}$ & Zech et al., 2007 \\
\hline Wara wara & S 17.28 & 66.11 & 4330 & $10 \mathrm{Be}$ & Zech et al., 2009 \\
\hline Tres lagunas & S 22.2 & 65.11 & 4563 & $10 \mathrm{Be}$ & Zech et al., 2009 \\
\hline Coropuna & S 15.55 & 72.62 & 4830 & $3 \mathrm{He}$ & Bromley et al., 2009, 2011 \\
\hline Tunupa & S 19.82 & 67.64 & 4252 & $3 \mathrm{He}$ & Blard et al., 2013 \\
\hline
\end{tabular}

In this Colombian region, a very short dry season is observed from December to March while the maximum precipitation occurs from April to November with a mean value of about $920 \mathrm{~mm}(1970-2000)$ at $3750 \mathrm{~m}$ a.s.l. The wet season over the northern tropics is associated with the latitudinal shift of the Inter Tropical Convergence Zone (ITCZ) toward its northern most position. The mean annual temperature is about $6^{\circ} \mathrm{C}$ at $3716 \mathrm{~m}$ a.s.l. (1970-2000). The current Equilibrium Line Altitude (ELA) in Cordillera de Cocuy is about $4915 \mathrm{~m}$ a.s.1. (Jomelli et al., 2014). 


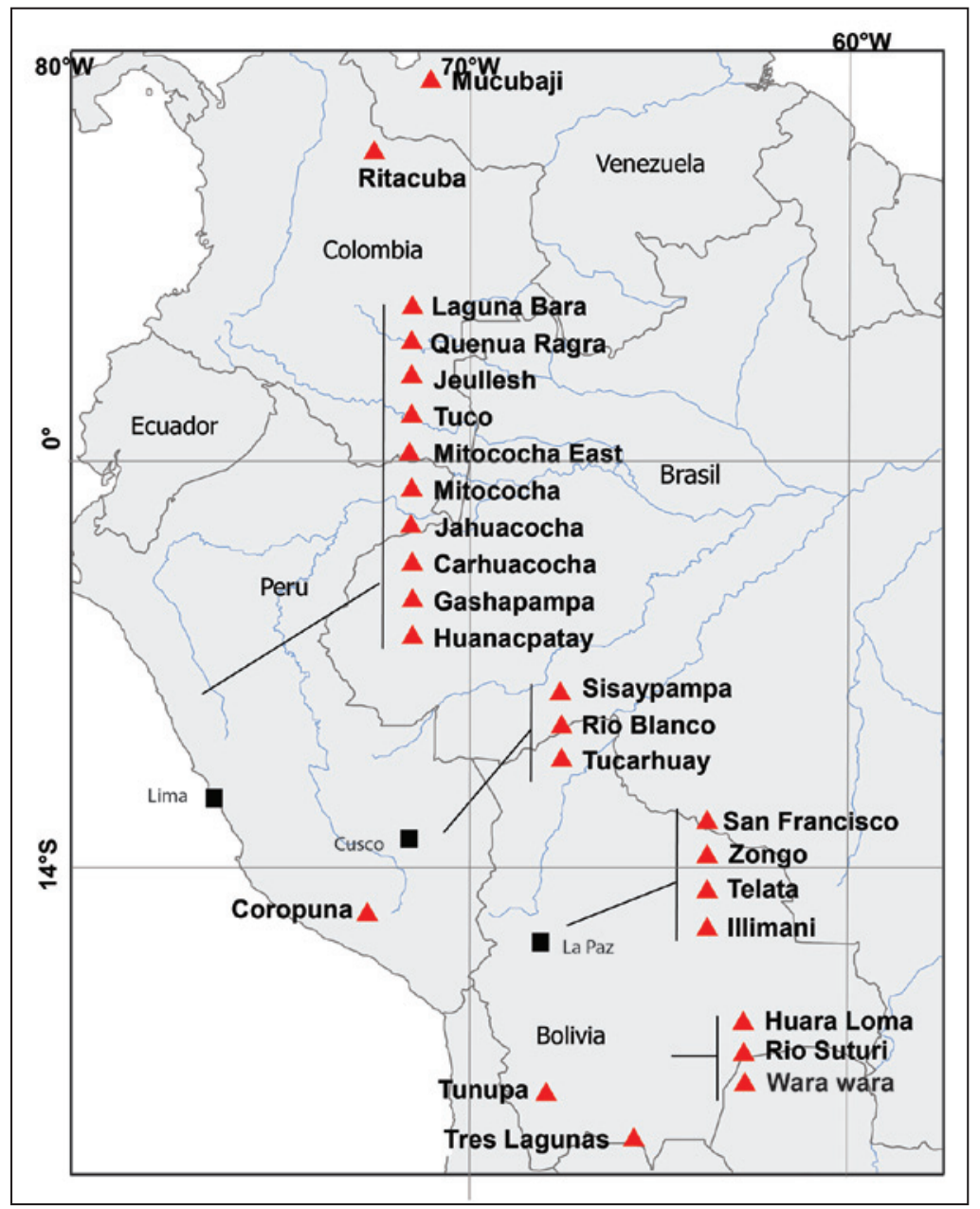

Figure 1. Location of the selected glaciers.

In the southern tropic twenty-one glaciers were selected in different cordilleras (Figs. 1 and 2). Ten glaciers were selected in the Peruvian Blanca and Huayhuash Cordilleras and three other glaciers in the Peruvian Vilcanota Cordillera near Cusco city. The White Cordillera $\left(9^{\circ} 10^{\prime} \mathrm{S}, 77^{\circ} 35^{\prime} \mathrm{W}\right)$ is the highest tropical mountain range in the world where e.g. Quenua Ragra is located. It extends over $180 \mathrm{~km}$ in length and comprises 35 peaks with an altitude greater than $6000 \mathrm{~m}$. The Huayhuash Cordillera is located in the south of the White Cordillera in Peru. It extends about $25 \mathrm{~km}$ long. Six summits of the Huayhuash mountain range exceed $6000 \mathrm{~m}$ a.s.l. and seven others are over $5500 \mathrm{~m}$ a.s.l. (e.g. Gashapampa glacier). Further south eight glaciers were selected along the Bolivian Oriental Cordilleras. Four glaciers were selected in the Cordillera Real with six peaks higher than $6000 \mathrm{~m}$ a.s.l. including Nevado Illimani 

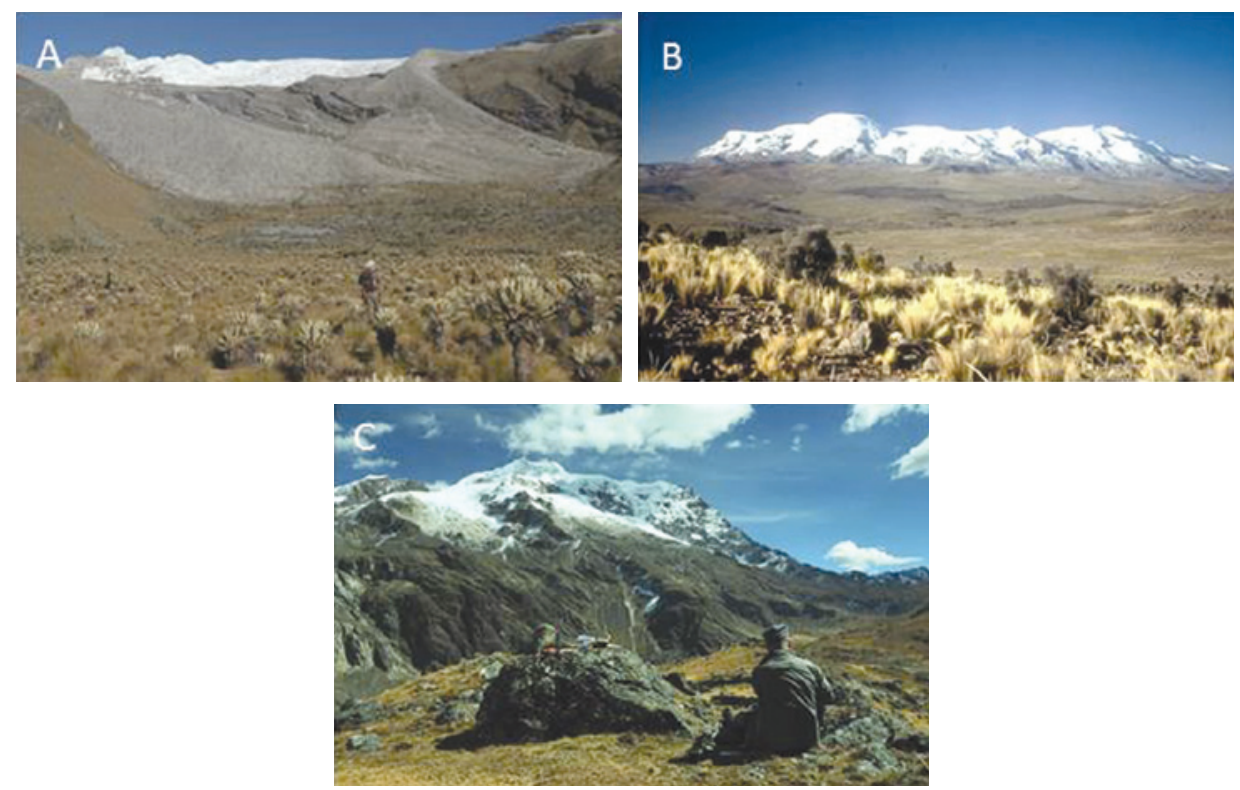

Figure 2. Ritacuba, Coropuna and Zongo glaciers selected in this paper.

summit (6400 m) near La Paz city. In these outer tropical cordilleras one wet season occurs, with tropical conditions prevailing from October to March, followed by a dry season with subtropical conditions prevailing from April to September. In the city of Cusco $(3219 \mathrm{~m})$ the average temperature varies from $12^{\circ} \mathrm{C}$ to $14^{\circ} \mathrm{C}$ during the warm season and from $9^{\circ} \mathrm{C}$ to $11^{\circ} \mathrm{C}$ during the cold season. Total annual precipitation ranges from 550 to $850 \mathrm{~mm}$ with more than $80 \%$ falling in the rainy season. In the Cordillera Blanca, the current ELA is at about $4950 \mathrm{~m}$ a.s.1., while it is at about $5240 \mathrm{~m}$ on Zongo glacier in the Bolivian Cordillera Real (Rabatel et al., 2013).

Finally we also recalculated ${ }^{3} \mathrm{He}$ moraine chronologies from two glaciers in the western Peruvian and Bolivian cordilleras. Here, the climate is drier with less than $500 \mathrm{~mm}$ of precipitation per year. On Coropuna volcano the current ELA oscillates around 5700 $\mathrm{m}$ but it is above $6000 \mathrm{~m}$ in southern Bolivia around Atacama Desert.

\section{Methods}

\subsection{Ages re-calculation}

The determination of an accurate CRE (Cosmic Ray Exposure) age relies on a priori knowledge of the production rate of the measured cosmogenic nuclide in a specific mineral (Balco et al., 2008). Because of the spatial and temporal variability of terrestrial cosmogenic nuclide production, the CRE age calculation requires transformation of a production rate value from its standard expression (i.e. for present sea level and high 
latitude conditions, SLHL) to a value that is adapted to the site of the CRE dating. This step relies on using one of the available scaling models (e.g. Dunai, 2001; Lal, 1991; Lifton et al., 2014; Stone, 2000), the choice of which introduces a model dependency on the final results and a related uncertainty that is difficult to assess. This dependency on the scaling model is reduced if the calibration site (from which the production rate is derived) and the dating site are close in space and time (Licciardi et al., 2009; Martin et al., 2015).

Jomelli et al. (2014) homogenized and recomputed 477 published ${ }^{10} \mathrm{Be}$ and $14{ }^{3} \mathrm{He}$ surface exposure ages in the tropical Andes covering the last 21,000 years. For the ${ }^{10} \mathrm{Be}$ ages, the process of homogenization was done as follow (Jomelli et al., 2014): first, ${ }^{10} \mathrm{Be}$ concentrations measured by accelerator mass spectrometry were all normalized to the assigned value of the 07KNSTD (Nishiizumi et al., 2007; Balco et al., 2008); second, existing ${ }^{10} \mathrm{Be}$ ages were recalculated using a production rate calibrated on the Altiplano (Blard et al., 2013a) and the Lal/Stone time dependent scaling factor (Stone, 2000; Balco et al., 2008). For ${ }^{3} \mathrm{He}$, the concentrations measured at CRPG Nancy were calibrated using the reference value of the 'CRONUS-Earth pyroxene intercomparison material' (Blard et al., 2015). Finally, the ${ }^{3} \mathrm{He}$ ages were computed using the production rate calibrated on the Altiplano (Blard et al., 2013b).

However, since the publication of Jomelli et al. (2014) new ${ }^{10} \mathrm{Be}$ and ${ }^{3} \mathrm{He}$ local production rates have been published (Martin et al., 2015; Delunel et al., 2016). The new ${ }^{10} \mathrm{Be}$ production rate in quartz used in this study is from Martin et al. (2015). These authors made a weighted mean of the three recently published rates from three Andean sites ranging from 3800 to $4900 \mathrm{~m}$ (Blard et al., 2013a; Kelly et al., 2015; Martin et al., 2015). These high tropical Andes production rates are very well clustered (Fig. 3). Similarly, the new ${ }^{3} \mathrm{He}$ production rate in the pyroxenes is based on the calibration studies of Blard et al. (2013b) and Delunel et al. (2016).

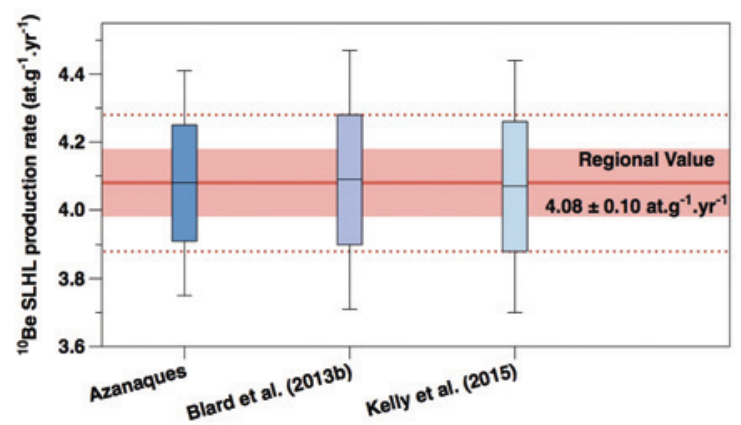

Figure $3 .{ }^{10}$ Be production rates in the high tropical Andes from 3 calibration studies, with their values represented by box plots (modified from Martin et al. [2015]). The scaling has been conducted using the "Lal modified" model (Balco et al., 2008), for a standard atmosphere and using the Muscheler et al. (2005) geomagnetic reconstruction. The body of the box and the whiskers indicate the $1 \sigma$ and $2 \sigma$ uncertainties respectively. The red shaded area and the red dotted lines show the $1 \sigma$ and $2 \sigma$ uncertainties of the regional value (weighted mean). 
For the integral re-calculation of the CRE ages, the scaling procedure is based on the Lal modified time dependant scaling scheme ( Lal, 1991; Stone, 2000; Balco et al., 2008) using the ERA-40 standard atmosphere (Uppala et al., 2005) and the Muscheler et al. (2005) Virtual Dipolar Moment (VDM) reconstruction. Borchers et al. (2015) showed that the Lal modified model and the LSD model (Lifton et al., 2014) were the most efficient models presently available to reduce discrepancies between the different calibration studies at the SLHL conditions. With the same type of approach Martin et al. (2015) showed that the Lal modified scheme yielded slightly better performance in the high Tropical Andes, especially when combined with the ERA-40 atmosphere and the Muscheler et al. (2005) VDM reconstruction. With this parameterization, we derived SLHL in situ production rates of $4.08 \pm 0.10$ at. $\mathrm{g}^{-1} . \mathrm{yr}^{-1}$ and $136 \pm 5$ at. $\mathrm{g}^{-1} \cdot \mathrm{yr}^{-1}$ for ${ }^{10} \mathrm{Be}$ and ${ }^{3} \mathrm{He}$, respectively, using the three ${ }^{10} \mathrm{Be}$ calibration sites (Martin et al., 2015) and the two ${ }^{3} \mathrm{He}$ calibration sites Blard et al. (2013b) and Delunel et al. (2016).

\subsection{Moraines selected in this study}

After the recalculation of the 477 published ${ }^{10} \mathrm{Be}$ and ${ }^{3} \mathrm{He}$ surface exposure ages from Jomelli et al. (2014), we excluded all moraines that yield exposure ages older than $14.5 \mathrm{ka}$, with the aim to focus on the ACR and YD-Holocene period (assuming that the ACR began at $14.5 \mathrm{kyr}$ ). This filtering retained $240{ }^{10} \mathrm{Be}$ and ${ }^{3} \mathrm{He}$ surface exposure ages from 25 different glaciers. To facilitate the comparison with the previous studies, moraine notation was strictly the same as the one used by authors in their original studies (Table 2). When the name was missing, we arbitrarily assigned an alphabetic letter to each of the documented moraines with $A$ corresponding to the moraine located closest to the current glacier front position (for example, see Glasser et al., 2009). This classification was based on our analysis of maps or aerial photos shown in the papers. We then calculated the age of each moraine following two distinct approaches. In the first approach, we strictly used or excluded the same samples as the authors did in their own analyses for the mean age moraine calculation. In a second approach, we applied a chi-square $\left(\chi^{2}\right)$ test for the calculation of the moraine ages.

\section{Results}

In order to document the number of glaciers with a maximum extent at the ACR or during a younger period, we distinguished 6 different chronozones. The first group corresponds to glaciers with a moraine possibly included in the ACR age bracket (14.5$12.9 \mathrm{ka}$ ), or older if we account for the uncertainty range, hereafter referred to as "pre ACR" (whose nominal values are older than $14.5 \mathrm{ka}$, but the uncertainties overlap with $14.5 \mathrm{ka}$ ) (orange in Fig. 4 and Tables 2-4), as is the case for Jeullesh glacier with a moraine dated to $14.5 \pm 0.3{ }^{10} \mathrm{Be} \mathrm{ka}$ ago. The second group corresponds to glaciers with a moraine dated during the ACR chronozone sensu stricto (red in Fig. 4). We applied the same principle for the four other groups named "ACR-YD", "YD" (sensu stricto 12.9-11.6 ka) (blue in Fig. 4) YD-Holocene (dark blue in Fig. 4) and Holocene with a documented moraine younger than $11.6 \mathrm{ka}$ ago (green in Fig. 4). 


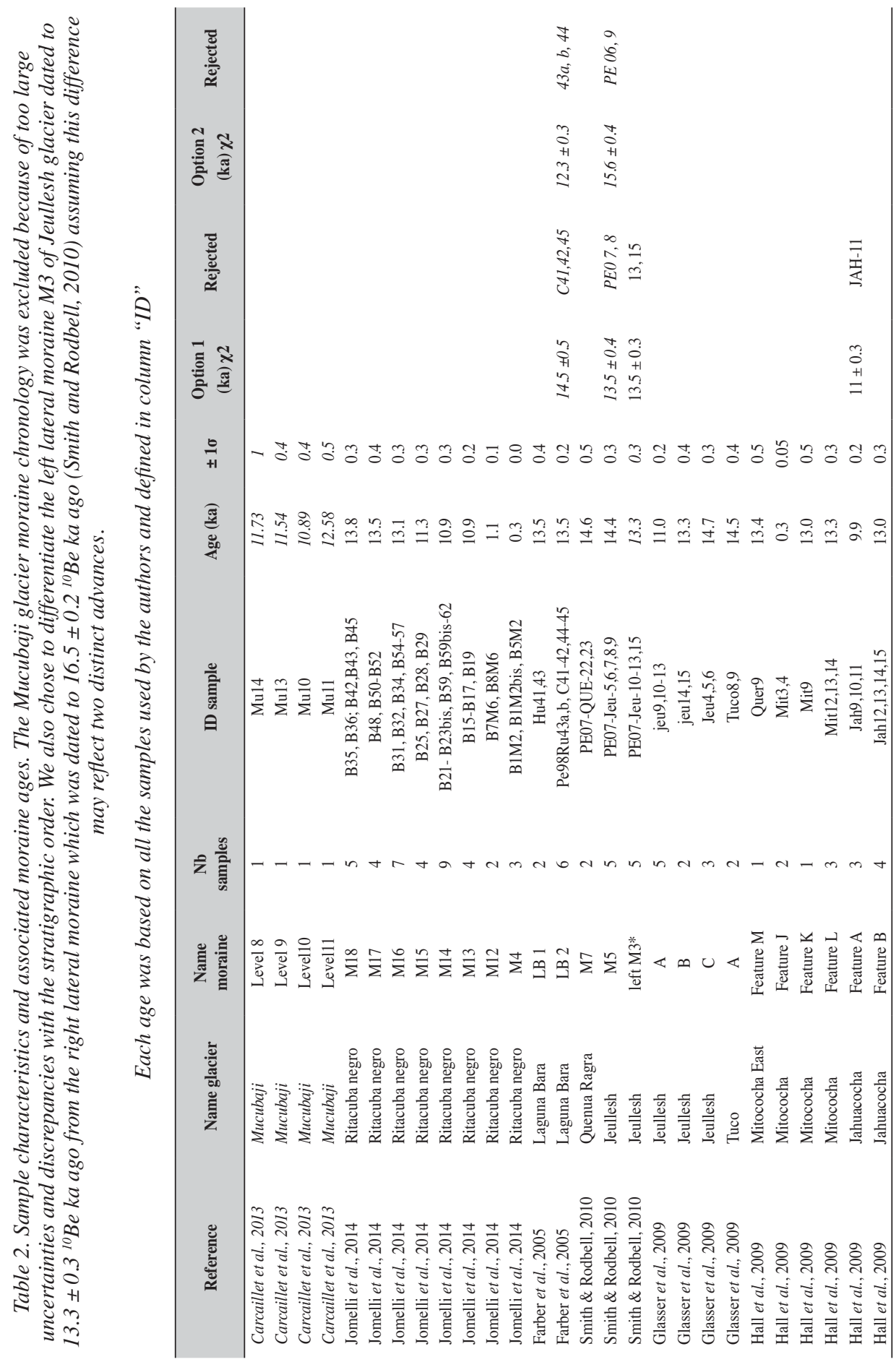




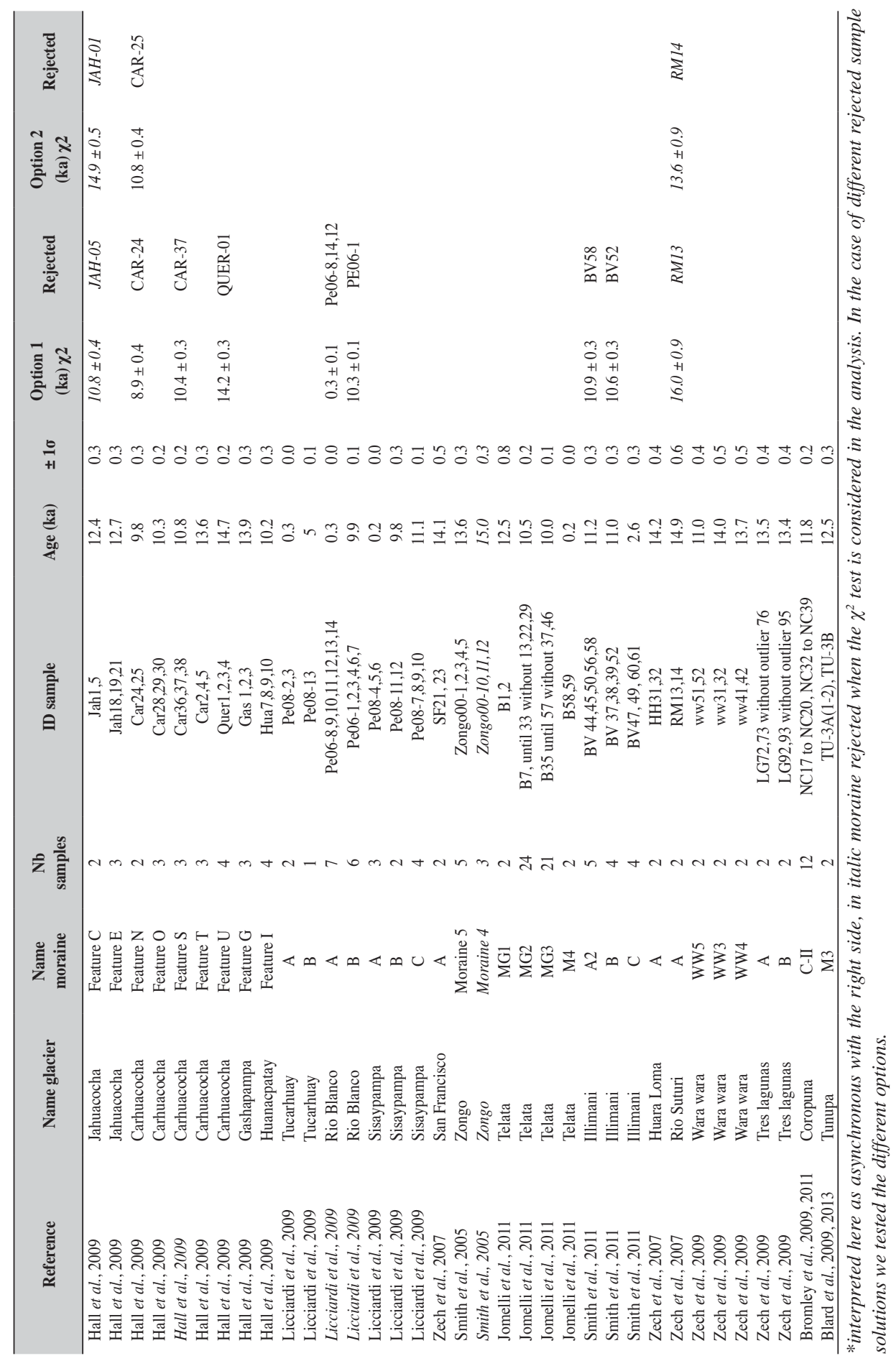




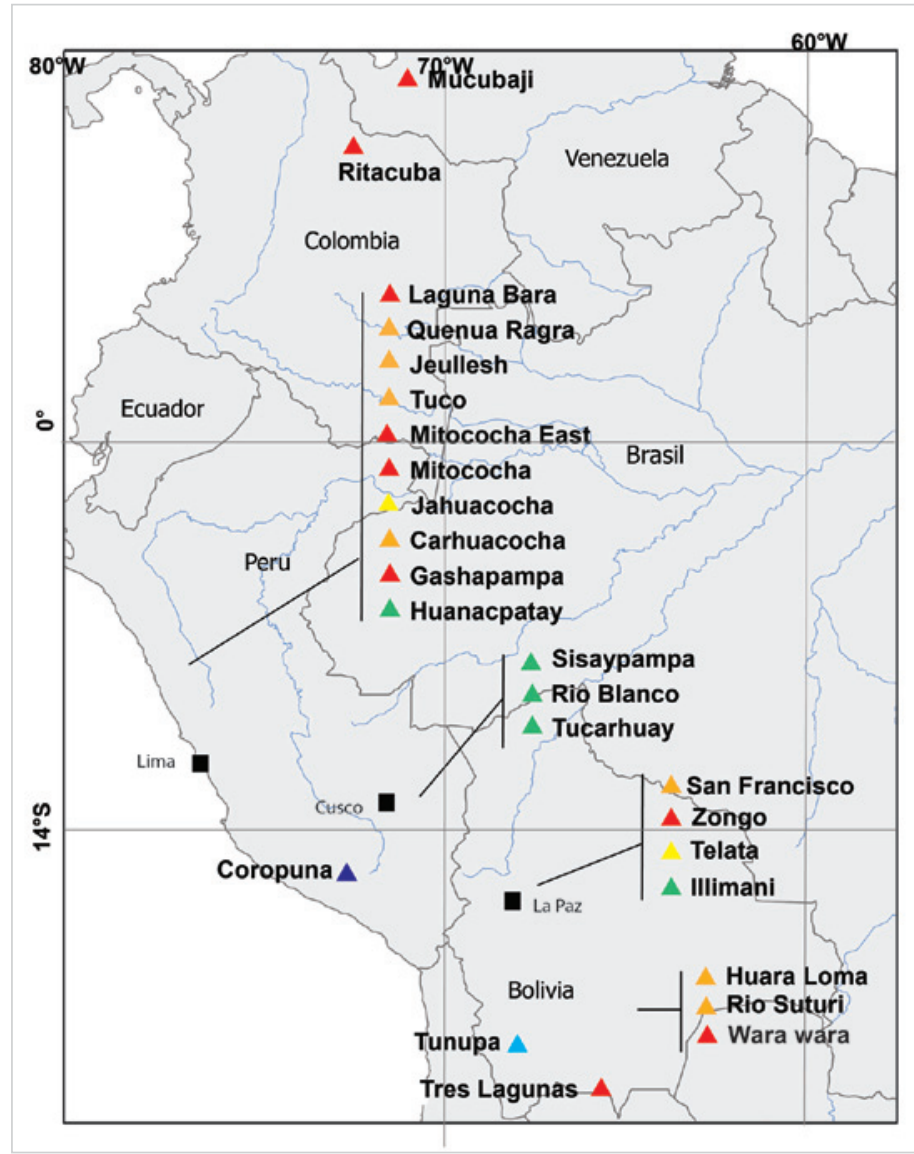

Figure 4. Location of the ${ }^{10} \mathrm{Be}$ and ${ }^{3} \mathrm{He}$ moraine record sites covering the northern and southern tropical Andes with the largest glacial advance dated to the ACR or possibly older (considering uncertainties) in orange, during the ACR in red, during the ACR or the YD (considering uncertainties) in yellow, during the YD in blue, during the YD or during the Holocene in dark blue, during the Holocene in green and rejected chronology in black without applying a $\chi^{2}$ test.

To determine the behavior of tropical glaciers, we next focused on two different calculations. First we considered the oldest dated moraine in the valley since the ACR period in order to document the timing of maximum extent per valley glacier over the last $14.5 \mathrm{ka}$. In the case of a glacier having a larger YD advance (compared to the ACR), this analysis should yield a YD signature only. Each glacier was classified in a single chronozone according to the age of the maximum extent moraine and its uncertainty. The number of glaciers (Tables 3-4) was then counted with and without applying a chi-square $\left(\chi^{2}\right)$ moraine age analysis. We excluded moraine ages when the $\chi^{2}$ test results were ambiguous yielding two possible moraine ages, which fall in different chronozones (this is detailed in options 1 and 2 in Table 2, see for instance moraine A of Rio Suturi glacier). 
Among the 24 glaciers (excluding Mucubaji glacier with moraine ages that do not respect the stratigraphic order) retained in this study, 15 glaciers $(60 \%)$ recorded their oldest moraine during the ACR or pre-ACR chronozone without chi-square $\left(\chi^{2}\right)$ moraine analysis (Table 3). 8 glaciers (32\%) recorded their oldest moraine dated to the ACR chronozone and 2 other glaciers showed their largest moraine belonging to the ACRYD group. Conversely only 4 glaciers showed their maximum extent dated to one of the three ACR-YD, YD and YD-Holocene groups. The application of the $\chi^{2}$ test does not change the predominance of the pre ACR-ACR moraine population. The number of glaciers showing the oldest ACR moraine is much larger than glaciers with their oldest moraines belonging exclusively to the YD (Table 4).

Table 3. Ages of maximum glacier extent without applying a $\chi^{2}$ test.

\begin{tabular}{|c|c|c|c|c|c|c|}
\hline Name glacier & Pre-ACR & ACR & ACR-YD & YD & YD-HOL & HOL \\
\hline Mucabaji & rejected & rejected & rejected & rejected & rejected & rejected \\
\hline Ritacuba & & 1 & & & & \\
\hline Laguna Bara & & 1 & & & & \\
\hline Quenua Ragra & 1 & & & & & \\
\hline Jeullesh* & 1 & & & & & \\
\hline Tuco & 1 & & & & & \\
\hline Mitococha East & & 1 & & & & \\
\hline Mitococha & & 1 & & & & \\
\hline Jahuacocha & & & 1 & & & \\
\hline Carhuacocha & 1 & & & & & \\
\hline Gashapampa & & 1 & & & & \\
\hline Huanacpatay & & & & & & 1 \\
\hline Tucarhuay & & & & & & 1 \\
\hline Rio Blanco & & & & & & 1 \\
\hline Sisaypampa & & & & & & 1 \\
\hline San Franc & 1 & & & & & \\
\hline Zongo & & 1 & & & & \\
\hline Telata & & & 1 & & & \\
\hline Illimani & & & & & & 1 \\
\hline Huara Loma & 1 & & & & & \\
\hline Rio Suturi & 1 & & & & & \\
\hline Wara wara & & 1 & & & & \\
\hline Tres lagunas & & 1 & & & & \\
\hline Coropuna & & & & & 1 & \\
\hline Tunupa & & & & 1 & & \\
\hline Total & 7 & 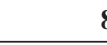 & 2 & & 1 & 5 \\
\hline
\end{tabular}

* Jeullesh is either Pre-ACR according to chronology in Glasser et al. (2009) or ACR according to chronology in Smith and Rodbell (2010). 
Table 4. Ages of maximum glacier extent when applying a $\chi^{2}$ test.

\begin{tabular}{|c|c|c|c|c|c|c|}
\hline Name glacier & Pre-ACR & ACR & ACR-YD & YD & YD-HOL & HOL \\
\hline Mucabaji & rejected & rejected & rejected & rejected & rejected & rejected \\
\hline Ritacuba & & 1 & & & & \\
\hline Laguna Bara & & 1 & & & & \\
\hline Quenua Ragra & 1 & & & & & \\
\hline Jeullesh* & 1 & & & & & \\
\hline Tuco & 1 & & & & & \\
\hline Mitococha East & & 1 & & & & \\
\hline Mitococha & & 1 & & & & \\
\hline Jahuacocha & & & 1 & & & \\
\hline Carhuacocha & 1 & & & & & \\
\hline Gashapampa & & 1 & & & & \\
\hline Huanacpatay & & & & & & 1 \\
\hline Tucarhuay & & & & & & 1 \\
\hline Rio Blanco & & & & & & 1 \\
\hline Sisaypampa & & & & & & 1 \\
\hline San Franc & 1 & & & & & \\
\hline Zongo & & 1 & & & & \\
\hline Telata & & & 1 & & & \\
\hline Illimani & & & & & & 1 \\
\hline Huara Loma & 1 & & & & & \\
\hline Rio Suturi & rejected & rejected & rejected & rejected & rejected & rejected \\
\hline Wara wara & & 1 & & & & \\
\hline Tres lagunas & & 1 & & & & \\
\hline Coropuna & & & & & 1 & \\
\hline Tunupa & & & & 1 & & \\
\hline Total & 6 & 8 & 2 & 1 & 1 & 5 \\
\hline
\end{tabular}

* based on the chronology of Glasser et al. (2009), but excluded if one considers the chronology in Smith and Rodbell (2010).

We then proceeded to the second calculation counting, this time counting the number of moraines dated to each of the different chronozone groups. Ages for which uncertainties are too large for a firm chronozone attribution were rejected from the analysis. 21 moraines (39\%) from the selected glaciers belong to the pre ACR-ACR chronozones while 8 moraines $(15 \%)$ only were dated to the ACR-YD, YD and YDHolocene groups (Table 5-6). Again the application of the $\chi^{2}$ test does not change the predominance of a pre-ACR-ACR chronozones signal. The highest number of moraines synchronous with the ACR was found on Ritacuba glacier located in Colombia, suggesting at least 3 distinct advances and/or stillstands during this period. 
Table 5. Number of moraines dated to each chronozone without applying a $\chi^{2}$ test.

\begin{tabular}{|c|c|c|c|c|c|c|}
\hline Name glacier & Pre-ACR & ACR & ACR-YD & YD & YD-HOL & HOL \\
\hline Mucabaji & rejected & rejected & rejected & rejected & rejected & rejected \\
\hline Ritacuba & & 3 & & & 1 & 4 \\
\hline Laguna Bara & 2 & & & & & \\
\hline Quenua Ragra & 1 & & & & & \\
\hline Jeullesh & 1 & $1 *$ & & & & $1 *$ \\
\hline Tuco & 1 & & & & & \\
\hline Mitococha East & & 1 & & & & \\
\hline Mitococha & & 1 & 1 & & & 1 \\
\hline Jahuacocha & & & 2 & 1 & & 1 \\
\hline Carhuacocha & 1 & 1 & & & & 3 \\
\hline Gashapampa & 1 & & & & & \\
\hline Huanacpatay & & & & & 1 & 1 \\
\hline Tucarhuay & & & & & & 2 \\
\hline Rio Blanco & & & & & & 2 \\
\hline Sisaypampa & & & & & & 3 \\
\hline San Franc & 1 & & & & & \\
\hline Zongo & & 1 & & & & \\
\hline Telata & & & 1 & & & 3 \\
\hline Illimani & & & & & & 3 \\
\hline Huara Loma & 1 & & & & & \\
\hline Riosuturi & 1 & & & & & \\
\hline Wara wara & & 2 & & & & 1 \\
\hline Tres lagunas & & 2 & & & & \\
\hline Coropuna & & & & & 1 & \\
\hline Tunupa & & & & 1 & & \\
\hline Total & 7 & 14 & 4 & 2 & 2 & 24 \\
\hline
\end{tabular}

* Based on the chronology in Glasser et al. (2009) exclusively.

Table 6. Number of moraines dated to each chronozone when applying a $\chi^{2}$ test.

\begin{tabular}{lcccccr} 
Name glacier & Pre-ACR & ACR & ACR-YD & YD & YD-HOL & HOL \\
\hline Mucabaji & rejected & rejected & rejected & rejected & rejected & rejected \\
Ritacuba & & 3 & & & 4 & 4 \\
Laguna Bara & & 1 & & & 1 \\
Quenua Ragra & 1 & & & & \\
Jeullesh & 1 & $1 *$ & & & \\
Tuco & 1 & & & & &
\end{tabular}




Mitococha
Jahuacocha
Carhuacocha
Gashapampa

\section{Discussion}

A recent paper based on 84 high-resolution terrestrial and marine southern hemisphere palaeoclimate time series revealed a progressive decrease of the intensity of the ACR signal from Antarctica to the northern regions (Pedro et al., 2016). A strong ACR signal is most common in the Antarctic, whereas a mixture of strong and weak ACR signals are seen in the Southern Ocean, South Atlantic and terrestrial lower latitudes. Lowland regions in the subtropics and tropics of South America do not show a clear trend. For instance, speleothems from western Amazonia show hydrologic variations that are highly correlated with North Atlantic climate signals expressed in Greenland ice cores (Mosblech et al., 2012; Cheng et al., 2013). Lake level fluctuations in Bolivia support a strong impact of the North Atlantic events on the hydrology of the Southern Tropical Andes (Sylvestre et al, 1999; Placzek et al., 2006; Blard et al., 2011). In South African regions, lacustrine records ( $\left.7^{\circ} \mathrm{S}\right)$ also suggest millennial-scale hydrologic variability in phase with the North Atlantic rather than with Antarctica (Schefuss et al., 2011).

Our meta-analysis of the Tropical Andes glaciers chronologies with the most upto-date production rates of Martin et al. (2015) and Delunel et al. (2016) do not change the main conclusions of Jomelli et al. (2014): over the last $15 \mathrm{ka}$, tropical Andean glaciers predominantly reached their maximum extent during the ACR. These findings 
raise the question of the latitudinal and longitudinal boundaries within which glaciers significantly advanced as response to the ACR signal, and their significance relative to the other paleoclimatic proxies from the same regions.

In South America, moraine records selected along different cordilleras from Patagonia to high-altitude glacier records in Bolivia-Peru (this study) revealed glacier advances during the ACR, whatever the latitude. Event in the northern tropics of Colombia $\left(6^{\circ} \mathrm{N}\right)$ our study showed that at least one glacier exhibited moraines formed during the ACR. Further north, a recent study conducted in Mexico (Vázquez-Selem and Lachniet, 2017) revealed, on the other hand, that glaciers expressed a North Atlantic climate signal with a major glacier advance during the YD chronozone.

Other moraine records selected in other southern mid latitude mountain regions such as in the South Island of New Zealand revealed a re-advance of glaciers during the ACR period (Putnam et al., 2010). All together these results suggest that moraine records are a very good proxy to document the ACR signal in the southern hemisphere.

The difference of pattern of change between glacier records and other proxies during the ACR period may be related to their respective sensitivity to temperature and precipitation changes. Recent papers (Jomelli et al., 2011; 2014; Shakun et al., 2016) revealed that long term glacier fluctuations including those in the tropical Andes are mostly driven by temperature changes which may explain the homogeneous glacier behavior during the ACR-YD period and the sensitivity of tropical glaciers to the ACR signal. Yet this overall trend can be challenged at a regional scale due to peculiarities of the hydrological cycle, as for the Altiplano.

\section{Conclusion}

This paper reevaluates the Andean tropical glacier behavior during the time span between the ACR and the Holocene. Based on a recalculation of 226 ages from 53 moraines from 24 glaciers, we examined the maximum glacier extent of the last 14,500 years and the most frequent occurrences of preserved moraines in the five groups of ages from the pre ACR to the Holocene, respectively. Results show that about $60 \%$ of glaciers recorded at least one advance during the pre-ACR-ACR periods. 21 moraines (40\%) of the selected glacier belong to the pre-ACR-ACR chronozones, while 3 moraines only (5\%) were dated to the YD and YD-Holocene groups. Several other moraine records selected in other southern mid latitudes mountain regions also revealed glacier readvances during the ACR period and demonstrate that moraine records are a very good proxy to document the ACR signal in the southern hemisphere.

\section{Acknowledgements}

This study was partly funded by the IRD-LMI Great Ice. We also acknowledge people who took part in the field campaign. We would like to extend our thanks both to I. Schimmelpfennig and an anonymous reviewer for their constructive remarks on an earlier version of this paper. 


\section{References}

Balco, G., Stone, J.O., Lifton, N.A., Dunai, T.J. 2008. A complete and easily accessible means of calculating surface exposure ages or erosion rates from ${ }^{10} \mathrm{Be}$ and $26 \mathrm{Al}$ measurements. Quaternary Geochronology 3, 174-195. http://doi.org/10.1016/j.quageo.2007.12.001.

Blard, P.H., Sylvestre, F., Tripati, A.K., Claude, C., Coudrain, A., Condom, T., Seidel, J.L., Vimeux, F., Moreau, C., Dumoulin, J.P., Lavé, J. 2011. Lake highstands on the Altiplano (Tropical Andes) contemporaneous with Heinrich 1 and the Younger Dryas: new insights from ${ }^{14} \mathrm{C}$, U-Th dating and $\delta^{18} \mathrm{O}$ of carbonates. Quaternary Science Reviews 30, 3973-3989. http://doi.org/10.1016/j.quascirev.2011.11.001.

Blard, P.H., Braucher, R., Lavé, J., Bourlès, D. 2013a. Cosmogenic ${ }^{10}$ Be production rate calibrated against ${ }^{3} \mathrm{He}$ in the high Tropical Andes (3800-4900 m, 20-22 $\left.{ }^{\circ} \mathrm{S}\right)$. Earth and Planetary Science Letters 382, 140-149. http://doi.org/10.1016/j.eps1.2013.09.010.

Blard, P.H., Lavé, J., Sylvestre, F., Placzek, C.J., Claude, C., Galy, V., Condom, T., Tibari, B. 2013b. Cosmogenic ${ }^{3} \mathrm{He}$ production rate in the high tropical Andes $\left(3800 \mathrm{~m}, 20^{\circ} \mathrm{S}\right)$ : Implications for the local Last Glacial Maximum. Earth and Planetary Science Letters 377-378, 260-275. http://doi.org/10.1016/j.eps1.2013.07.006.

Blard, P.H., Balco, G. Burnard, P.G., Farley, K.A., Fenton, C.R., Friedrich, R., Jull, A.J.T., Niedermann, S. Pik, R., Schaefer, J.M., Scott, E.M., Shuster, D.L., Stuart, F.M., Stute, M., Tibari, B.,Winckler, G., Zimmermann L. 2015. An inter-laboratory comparison of cosmogenic ${ }^{3} \mathrm{He}$ and radiogenic ${ }^{4} \mathrm{He}$ in the CRONUS-P pyroxene standard. Quaternary Geochronology 26, 11-19.

Borchers, B., Marrero, S., Balco, G., Caffee, M., Goehring, B., Lifton, N., Nishiizumi, K., Phillips, F., Schaefer, J., Stone, J. 2015. Geological calibration of spallation production rates in the CRONUS-Earth project. Quaternary Geochronology 31, 188-198. http://doi. org/10.1016/j.quageo.2015.01.009.

Bromley, G.R.M., Schaefer, J.M., Winckler, G., Hall, B.L., Todd, C.E., Rademaker, K.M. 2009. Relative timing of last glacial maximum and late-glacial events in the central tropical Andes. Quaternary Science Reviews 28 (23-24), 2514-2526. http://doi.org/10.1016/j. quascirev.2009.05.012.

Bromley, G.R.M., Hall, B.L. 2011. Glacier fluctuations in the southern Peruvian Andes during the late-glacial period, constrained with cosmogenic 3He. Journal of Quaternary Science 26, 37-43. http://doi.org/10.1002/jqs.1424.

Carcaillet, J., Angel, I., Carrillo, E., Audemard, F. A. Beck, C. 2013. Timing of the last deglaciation in the Sierra Nevada of the Merida Andes, Venezuela. Quaternary Research 80, 482-494. http://doi.org/10.1016/j.yqres.2013.08.001.

Cheng, H., Sinha, A., Cruz, F.W., Wang, X., Edwards, R.L., d'Horta, F.M., Ribas, C.C., Vuille, M., Stott, L.D., Auler, A.S. 2013: Climate change patterns in Amazonia and biodiversity. Nature Communications 4, 1411. http://doi.org/10.1038/ncomms2415.

Delunel, R., Blard, P.H., Martin, L.C.P., Nomade, S., Schlunegger, F. 2016. Long term low latitude and high elevation cosmogenic ${ }^{3} \mathrm{He}$ production rate inferred from a 107 ka-old lava flow in northern Chile; $22^{\circ} \mathrm{S} 3400 \mathrm{~m}$ a.s.1. Geochimica Cosmochimica Acta 184, 71-87. http://doi.org/10.1016/j.gca.2016.04.023.

Dunai, T. 2001. Influence of secular variation of the geomagnetic field on production rates of in situ produced cosmogenic nuclides. Earth and Planetary Science Letters 193, 197-212. http://doi.org/10.1016/S0012-821X(01)00503-9.

Farber, D.L., Hancock, G.S., Finkel, R.C., Rodbell, D.T. 2005. The age and extent of tropical alpine glaciation in the Cordillera Blanca, Peru. Journal of Quaternary Science 20, 759-776. http://doi.org/10.1002/jqs.994. 
Glasser, N.F., Clemmens, S., Schnabel, C., Fenton, C.R., McHargue, L. 2009. Tropical glacier fluctuations in the Cordillera Blanca, Peru between 12.5 and $7.6 \mathrm{ka}$ from cosmogenic ${ }^{10} \mathrm{Be}$ dating. Quaternary Science Reviews 28, 3448-3458. http://doi.org/10.1016/j. quascirev.2009.10.006.

Hall, S.R., Farber, D.L., Ramage, J.M., Rodbell, D.T., Finkel, R.C., Smith, J.A., Mark, B.G., Kassel, C. 2009. Geochronology of Quaternary glaciations from the tropical Cordillera Huayhuash, Peru. Quaternary Science Reviews 28, 2991-3009. http://doi.org/10.1016/j. quascirev.2009.08.004.

Jomelli, V., Khodri, M., Favier, V., Brunstein, D., Ledru, M.P., Wagnon, P., Blard, P.H., Sicart, J.E., Braucher, R., Grancher, D., Bourlès, D.L., Braconnot, P., Vuille, M. 2011. Irregular tropical glacier retreat over the Holocene. Nature 474, 196-199, http://doi.org/10.1038/ nature 10150.

Jomelli, V., Favier, V., Vuille, M., Braucher, R., Blard, P.H., Khodri, M., Colose, C., Brunstein, D., Bourlès, D., Leanni, L., Rinterknecht, V., Grancher, D., Francou, B., He, F., Ceballos, J.L., Francesca, H., Liu, Z., Otto-Bliesner, B. 2014. A major advance of tropical Andean glaciers during the Antarctic Cold Reaversal. Nature 513, 224-228. http://doi.org/10.1038/ nature 13546.

Kaser, G. 2001. Glacier-climate interaction at low latitudes. Journal of Glaciology 47, 195-204. http://doi.org/10.3189/172756501781832296.

Kelly, M. A., Lowell, T. V., Applegate, P.J., Phillips, F.M., Schaefer, J.M., Smith, C.A., Kim, H., Leonard, K.C., Hudson, A.M. 2015. A locally calibrated, late glacial 10Be production rate from a low-latitude, high-altitude site in the Peruvian Andes. Quaternary Geochronology 26, 70-85. http://doi.org/10.1016/j.quageo.2013.10.007.

Lal, D. 1991. Cosmic ray labeling of erosion surfaces: in situ nuclide production rates and erosion models. Earth and Planetary Science Letters 104, 424-439. http://doi.org/10.1016/0012821X(91)90220-C.

Licciardi, J.M., Schaefer, J.M., Taggart, J.R., Lund, D.C. 2009. Holocene glacier fluctuations in the Peruvian Andes indicate northern climate linkages. Science 325, 1677-1679. http://doi. org/10.1126/science.1175010.

Lifton, N., Sato, T., Dunai, T.J. 2014. Scaling in situ cosmogenic nuclide production rates using analytical approximations to atmospheric cosmic-ray fluxes. Earth and Planetary Science Letters 386, 149-160. http://doi.org/10.1016/j.epsl.2013.10.052.

Martin, L., Blard, P.H., Lave, J., Braucher, R., Lupker, M., Condom, T., Charreau, J., Mariotti, V., Bourlès, D., Arnold, M., G. Keddadouche, K.A., Davy, E. 2015. In situ cosmogenic 10Be production rate in the High Tropical Andes. Quaternary Geochronology 30, 54-68. http://doi. org/10.1016/j.quageo.2015.06.012.

Mosblech, N.A.S. Bush, M.B., Gosling, W., L., Hodell, D., Thomas, L., van Calsteren, P., Correa-Metrio, A., Valencia, B.G., Curtis, J., van Woesik, R. 2012. North Atlantic forcing of Amazonian precipitation during the last ice age. Nature Geoscience 5, 817-820. http://doi. org/10.1038/ngeo1588.

Muscheler, R., Beer, J., Kubik, P.W., Synal, H. 2005. Geomagnetic field intensity during the last 60,000 years based on $10 \mathrm{Be}$ and $36 \mathrm{Cl}$ from the Summit ice cores and 14C. Quaternary Science Reviews 24, 1849-1860. http://doi.org/10.1016/j.quascirev.2005.01.012.

Nishiizumi, K, Imamura, M., Caffee, M.W., Southon, J.R., Finkel, R.C., Mc Aninch, J. 2007. Absolute calibration of ${ }^{10} \mathrm{Be}$ AMS standards. Nuclear Instruments and Methods in Physics Research B 258, 403-413.

Pedro, J.B., Bostock, H.C., Bitz, C.M., He, F., Vandergoes, M.J., Steig, E.J., Chase, B.M. Krause, C.E., Rasmussen, S.O., Bradley, R., Cortese, G. 2016. The spatial extent and dynamics of the Antarctic Cold Reversal. Nature Geoscience 9, 51-55. http://doi. org/10.1038/ngeo2580. 
Placzek, C., Quade, J., Patchett, P.J. 2006. Geochronology and stratigraphy of late Pleistocene lake cycles on the southern Bolivian Altiplano: implications for causes of tropical climate change. Geological Society of America Bulletin 118, 515-532.

Putnam, A.E., Denton, G.H., Schaefer, J.M., Barrell, D.J.A., Andersen, B.G., Finkel, R., Schwartz, R., Dughty, A.M., Kaplan, M., Schlüchter, C. 2010. Glacier advance in southern middlelatitudes during the Antarctic Cold Reversal. Nature Geoscience 3, 700-704. http://doi. org/10.1038/ngeo962.

Rabatel, A., Francou, B., Soruco, A., Gomez, J., Cáceres, B., Ceballos, J.L., Basantes, R., Vuille, M., Sicart, J.E., Huggel, C., Scheel, M., Lejeune, Y., Arnaud, Y., Collet, M., Condom, T., Consoli, G., Favier, V., Jomelli, V., Galarraga, R., Ginot, P., Maisincho, L., Mendoza, J., Ménégoz, M., Ramirez, E., Ribstein, P., Suarez, W., Villacis, W., Wagnon, P. 2013. Current state of glaciers in the tropical Andes. A multi century perspective on glacier evolution and climate change. The Cryosphere 7, 81-102. http://doi.org/10.5195/tc-7-81-2013.

Rodbell, D. T., Smith, J. A., Mark, B. G. 2009. Glaciation in the Andes during the lateglacial and Holocene. Quatary Science Reviews 28, 2165-2212. http://doi.org/10.1016/j. quascirev.2009.03.012.

Schefuss, E., Kuhlmann, H., Mollenhauer, G., Prange, M., Pätzold, J. 2011. Forcing of wet phases in southeast Africa over the past 17,000 years. Nature 480, 509-512. http://doi.org/10.1038/ nature 10685 .

Shakun J.D., Clark, P.U., He, F., Lifton, N.A., Liu, Z. Otto-Bliesne, B.L. 2015 Regional and global forcing of glacier retreat during the last deglaciation. Nature Communications 6, 8059. http:// doi.org/10.1038/ncomms9059.

Sylvestre, F., Servant-Vildary, S., Servant, M., Causse, C., Fournier, M., Ybert, J.P. 1999. Lakelevel chronology on the Southern Bolivian Altiplano (18-23 $\left.{ }^{\circ} \mathrm{S}\right)$ during Late-Glacial Time and the Early Holocene. Quaternary Research 51, 54-66.

Smith, J.A., Seltzer, G.O., Farber, D.L., Rodbell, D.T. , Finkel, R.C. 2005. Early local last glacial maximum in the tropical Andes. Science 308, 678-681. http://doi.org/10.1126/ science. 1107075 .

Smith J.A., Rodbell, D.T. 2010. Cross-cutting moraines reveal evidence for North Atlantic influence on glaciers in the tropical Andes. Journal of Quaternary Science 25, 243-248. http://doi.org/10.1002/jqs.1393.

Smith, C.A., Lowell, T.V., Owen, L.A., Caffee, M.W. 2011. Late Quaternary glacial chronology on Nevado Illimani, Bolivia, and the implications for paleoclimatic reconstructions across the Andes. Quaternary Research 75, 1-10. http://doi.org/10.1016/yqres.2010.07.001 .

Stone, J.O. 2000. Air pressure and cosmogenic isotope production. Journal of Geophysical Research 105, 23753. http://doi.org/10.1029/2000JB900181.

Strelin, J.A., Kaplan, M.R., Vandergoes, M.J., Denton, G.H., Schaefer, J.M. 2014. Holocene glacier history of the Lago Argentino basin, Southern Patagonian Icefield. Quaternary Science Reviews 101, 124-145. http://doi.org/10.1016/j.quascirev.2014.06.026.

Thompson, L., Mosley-Thompson, E., Henderson, K. 2000. Ice-core palaeoclimate records in tropical South America since the last glacial maximum. Journal of Quaternary Science 15, 377-394. http://doi.org/10.1002/1099-1417(200005)15:4<377::AID-JQS542>3.0.CO;2-L.

Thompson, L.G., Mosley-Thompson, E., Brecher, H., Davis, M., Leon, B., Les, D., Lin, P.N., Mashiotta, T., Mountain, K. 2006. Abrupt tropical climate change: past and present. PNAS 103, 10536-10543.

Uppala, S.M., Kållberg, P.W., Simmons, A.J., Andrae, U., Da Costa Bechtold, V., Fiorino, M., Gibson, J.K., Haseler, J., Hernandez, A., Kelly, G.A., Li, X., Onogi, K., Saarinen, S., Sokka, N., Allan, R.P., Andersson, E., Arpe, K., Balmaseda, M.A., Beljaars, A.C.M., Van de Berg, L., Bidlot, J., Bormann, N., Caires, S., Chevallier, F., Dethof, A., Dragosavac, M., Fisher, M., Fuentes, M., Hagemann, S., Hólm, E., Hoskins, B.J., Isaksen, L., Janssen, P.A.E.M., 
Jenne, R., Mcnally, A.P., Mahfouf, J.F., Morcrett, J.J., Rayner, N.A., Saunders, R.W., Simon, P., Sterl, A., Trenberth, K.E., Untch, A., Vasiljevic, D., Viterbo, P., Woollen, J. 2005. The Era-40 re-analysis. Quarterly Journal of the Royal Meteorological Society 131. http://doi. org/10.1256/qj.04.176.

Vázquez-Selem, L., Lachniet, M. 2017. The deglaciation of the mountains of Mexico and Central America. Cuadernos de Investigación Geográfica 43 (2), 553-570. http://doi.org/10.18172/ cig.3238.

Zech, R., Kull, C., Kubik, P.W., Veit, H. 2007. LGM and Late Glacial glacier advances in the Cordillera Real and Cochabamba (Bolivia) deduced from 10Be surface exposure dating. Climate of the Past 3, 623-635. http://doi.org/10.5194/cp-3-623-2007.

Zech, J., Zech, R., Kubik, P.W., Veit, H. 2009. Glacier and climate reconstruction at Tres Lagunas, NW Argentina, based on 10Be surface exposure dating and lake sediment analyses. Palaeogeography, Palaeoclimatology, Palaeoecology 284, 180-190. http://doi.org/10.1016/j. palaeo.2009.09.023. 